\title{
PENGGUNAAN KOMUNIKASI INSTRUKSIONAL OLEH PENDIDIK DI TAMAN PENDIDIKAN AL QUR'AN
}

\author{
Ismaliza April*
}

\begin{abstract}
The general purpose of this research was to explore the utilization of instructional communication by the teachers in the Al Qur'an Education Institution. Specifically the research aimed at describing the use of instructional communication by the teachers based on verbal communication, non-verbal communication, and communication with media. The resultf of the research shows that the teachers of the Al Qur'an Education Institution of Husnul Khatimah has been using instructional communication properly. Eventhough, this research gives some suggestions to improve the teachers' competence in using the instructional communication.
\end{abstract}

Key words: communication, instructional communication, media

\section{Abstrak}

Tujuan umum penelitian ini untuk melihat penggunaan komunikasi instruksional oleh pendidik pada Taman Pendidikan Al Qur'an khususnya penelitian ini bertujuan untuk menggambarkan: (1) penggunaan komunikasi instruksional oleh penididik dilihat dari komunikasi verbal, (2) penggunaan komunikasi instruksional oleh pendidik dilihat dari komunikasi nonverbal, (3) penggunaan komunikasi instruksional oleh pendidik dilihat dari komunikasi dengan menggunakan media. Data dikumpulkan melalui teknik wawancara yang hasilnya diolah secara deskriptif. Hasil penelitian ini menunjukkan bahwa para pendidik di TPK Husnul Khatimah telah menggunakan komunikasi instruksional secara tepat. Sungguhpun demikian, penelitian ini memberikan sejumlah saran untuk meningkatkan kemampuan pendidik dalam menggunakan komunikasi instruksional.

Kata-kata kunci: komunikasi, komunikasi instruksional, media

\section{PENDAHULUAN}

Pendidikan berfungsi mengembangkan kemampuan serta potensi yang dimiliki oleh peserta didik yang berkreativitas tinggi dan berilmu pengetahuan sehingga akan terciptanya SDM yang inovatif dan berpikir kritis dalam menyongsong masa depan nantinya. Sebagaimana yang ditegaskan dalam Undang-Undang No.20 Tahun 2003 yaitu pendidikan nasional berfungsi mengembangkan kemampuan dan membantu watak serta peradaban bangsa yang bermartabat dalam rangka mencerdaskan kehidupan bangsa bertujuan untuk berkembangnya potensi peserta didik agar menjadi manusia yang beriman dan bertaqwa kepada Tuhan Yang Maha Esa, berahlak mulia, sehat, berilmu, cakap, kreatif, mandiri, menjadi warga negara yang demokratis, serta bertanggung jawab"

Mutu pendidikan akan menunjukan berhasil atau

* Mahasiswa Rintisan Pendidikan Gelar (RPG) PTK-PNF Tahun 2007 UNP Sumatera Barat tidaknya pembangunan nasional. Sehubungan dengan itu sudah jelas bahwa untuk memperoleh pendidikan tidak hanya di sekolah saja, tetapi juga bisa didapat melalui jalur Pendidikan Luar Sekolah. Dalam UndangUndang No.20 Tahun 2003 dijelaskan bahwa sistem pendidikan nasional dilaksanakan melalui tiga jalur, yaitu jalur pendidikan formal, informal dan nonformal. Tujuan Pendidikan Luar Sekolah (PLS) menurut UU RI No. 20 Tahun 2003 adalah sebagai berikut (a) melayani warga belajar supaya dapat tumbuh dan berkembang sedini mungkin dan sepanjang hayatnya guna meningkatkan dan mutu kehidupannya; (b) membina warga belajar agar memiliki pengetahuan, keterampilan, dan sikap mental yang diperlukan untuk mengembangkan diri, bekerja mencari nafkah, atau melanjutkan ke tingkat/jenjang yang lebih tinggi; dan (c) memenuhi kebutuhan warga belajar masyarakat yang tidak dapat dipenuhi dalam jalur pendidikan sekolah. Dalam pelak- 
sanaannya, PLS dibagi dalam beberapa jenis pendidikan. Jenis pendidikan luar sekolah terdiri atas pendidikan umum, pendidikan keagamaan, pendidikan jabatan kerja, pendidikan kedinasan, dan pendidikan kejuruan. (UU RI No.20 Tahun 2003). Salah satu wadah PLS untuk mencapai tujuan pendidikan nasional yaitu mewujudkan manusia yang beriman dan bertakwa kepada Tuhan YME adalah melalui Taman Pendidikan Al-Quran (TPA).

Berdasarkan observasi dan wawancara yang penulis lakukan dengan pimpinan TPA Husnul Khatimah merupakan TPA yang mendapat pengakuan baik oleh masyarakat. TPA ini merupakan TPA termuda yang berada di daerahnya dengan jumlah murid lebih banyak jika dibandingkan dengan TPA lainnya. TPA Husnul Khatimah berdiri tahun 2002 dan dikelola oleh oleh tiga orang pendidik dengan jumlah murid saat itu 145 orang. Dari tahun ke tahun sampai sekarang jumlahnya bertambah menjadi 152 orang yang juga berasal dari daerahnya tersebut. TPA Husnul Khatimah mengajarkan murid-muridnya mengenai ilmu agama, seperti ilmu tajwid, ilmu fiqih, irama, didikan subuh, menghafal ayat-ayat Al qur'an, Hadist, dan sebagainya.

Untuk mencapai tujuan pendidikannya maka TPA Husnul Khatimah perlu menciptakan iklim belajar yang kondusif, yaitu iklim belajar yang dapat mencapai efektivitas pencapaian tujuan pendidikan. Iklim belajar yang dimaksud adalah terdapatnya komunikasi dua arah, adanya keterlibatan dari peserta didik, adanya stimulus yang diberikan oleh pendidik kepada peserta didik, dan adanya respon dari peserta didik.Keterlibatan peserta didik sangat penting dan mendasar karena merupakan syarat pertama dan utama dalam kegiatan pembelajaran. Untuk terjadinya keterlibatan tersebut serta dapat menunjang pencapaian tujuan pendidikan, maka pendidik harus memiliki bermacam cara dalam upaya memajukan, merangsang dan membimbing proses pembelajaran. Salah satu caranya adalah pendidik hendaknya mampu menjalin komunikasi yang baik dengan peserta didik. Sebagaimana yang dikemukakan Koontz (dalam Fuadiansyah, 2007) bahwa "komunikasi sebagai sarana penghubung antar orang-orang dalam organisasi untuk mencapai tujuan bersama karena tanpa adanya komunikasi tidak mungkin ada aktivitas kelompok, dan tanpa hubungan yang harmonis aktivitas kelompok tidak akan berjalan sebagaimana yang diharapkan.

Pendapat di atas menjelaskan bahwa dengan terjalinnya komunikasi yang baik dalam interaksi pembelajaran, merupakan salah satu aspek yang mempengaruhi keberhasilan proses pembelajaran. Dalam proses komunikasi yang baik pendidik akan me- mandang peserta didik sebagai pribadi yang bisa diajak berdialog dan dapat memberikan tanggapan terhadap materi yang disampaikan. Dengan demikian akan berjalan proses pembelajaran secara baik yang pada akhirnya akan mempengaruhi baik buruknya hasil belajar peserta didik.

Dari hasil pengamatan dan wawancara yang penulis lakukakan, TPA ini sudah berhasil dalam menjalankan programnya. Hal ini dilihat dari hasil belajar, yakni pada tingkat III sudah mampu menghafal satu juzAlqur'an, mengerti tentang ilmu tajwid dan fiqih serta mengaji irama, yang teraplikasikan dalam bentuk prestasi menjuarai perlombaan MTQ pada tahun 2005. Prestasi lain yang diperoleh yaitu menjadi juara dalam acara pawai Ta'ruf yang diikuti peserta didik tingkat I, II, dan III. Selain itu, prestasi belajar yang didapat oleh peserta didik di sekolah pada mata pelajaran agama di atas rata-rata. Penulis melihat hal tersebut pada peserta didik tingkat III di TPA Husnul Khatimah pada tahun 2007/2008 yang berjumlah 42 orang. Untuk lebih jelasnya dapat dilihat pada tabel berikut.

Tabel.1. Daftar Nilai Peserta Didik Tingkat III TPA Husnul Khatimah pada Mata Pelajaran Agama dari Sekolah Tahun Ajaran 2007-2008.

\begin{tabular}{|c|c|c|c|c|c|l|}
\hline Mata & \multicolumn{4}{|c|}{ Nilai yang Diperoleh } & Ket. \\
\cline { 2 - 7 } Ajar & $\mathbf{9}$ & $\mathbf{8}$ & $\mathbf{7}$ & $\mathbf{6}$ & $\mathbf{5}$ & \\
\hline Tajwid & 5 org & 7 org & 3 org & 3 org & - & \\
\hline Irama & 3 org & 4 org & 2 org & - & - & \\
\hline Hfalan & 4 org & 6 org & 3 org & - & - & \\
\hline Jumlah & 12 org & 17 org & 10 org & 3 org & & 42 org \\
\hline
\end{tabular}

Dari tabel di atas dapat dilihat, bahwa TPA ini telah berhasil dalam melaksankan proses belajar mengajar yang berorientasi pada peran interaksi belajar mengajar. Salah satu faktor keberhasilan tersebut diduga berasal dari TPA Husnul Khatimah.

Berdasarkan uraian di atas, penelitian ini difokuskan pada penggunaan komunikasi instruksional oleh pendidik pada TPA Husnul Khatimah dalam bentuk komunikasi verbal, komunikasi nonverbal, dan komunikasi bermedia. Pertanyaan yang akan dicari jawabannya dengan penelitian ini adalah (1) bagaimanakah gambaran penggunaan komunikasi komunikasi instruksional dalam bentuk menyampain pesan secara verbal, (2) bagaimanakah gambaran penggunaan komunikasi instruksional dalam bentuk menyampaian pesan secara nonverbal, dan (3) bagaimanakah gambaran penggunaan komunikasi instruksional dalam bentuk menyampaikan pesan dengan menggunakan media?

Makna terbesar dari penelitian adalah memiliki 
manfaat bagi masyarakat, lembaga maupun perorangan. Manfaat praktis dari penelitian ini diuraikan sebagai masukan kepada (a) pengelola ataupun pendidik TPA Husnul Khatimah agar dapat dijadikan sebagai bahan perbaikan atau peningkatan kualitas komunikasi dalam proses belajar mengajar, (b) pengembangan ilmu Pendidikan Luar Sekolah khususnya mengenai komunikasi instruksional.

\section{KAJIAN TEORETIS}

Adapun kajian yang terkait dengan penelitian ini, akan peneliti uraikan dalam teori-teori, sebagai berikut. Pengertian Komunikasi

Pengertian komunikasi, Muhammad (2005:4) menyatakan bahwa "komunikasi adalah pertukaran pesan verbal maupun nonverbal antara si pengirim dengan si penerima pesan untuk mengubah tingkah laku".

Selanjutnya Onong (2000:57) menjelaskan jenis komunikasi antara lain a) komunikasi pribadi yang terbagi ke dalam komunikasi intrapribadi dan antarpribadi, b) komunikasi kelompok, c) komunikasi massa. Dalam membentuk sebuah proses komunikasi terdapat unsur-unsur yang saling terkait untuk mencapai tujuan.

Menurut Muhammad (2005), ada lima komponen atau unsur penting dalam komunikasi yang harus diperhatikan, yaitu 1) pengirim pesan (sender), 2) pesan yang disampaikan (message), 3) bagaimana pesan tersebut disampaikan (delivery channel), 4) penerima pesan (receiver), 5) umpan balik (feedback)". Pengirim pesan atau sumber komunikasi, yakni seseorang atau sekelompok atau suatu organisasi yang mengambil inisiatif mengirim pesan, dalam penelitian ini yang dimaksud dengan pengirim pesan atau sumber informasi adalah pendidik. Komunikasi yang efektif bukan hanya sekedar kata-kata yang digunakan tetapi juga mengikuti ekspresi wajah, intonasi, aksen, titik putus vokal, dan sebagainya.

Fungsi komunikasi dalam kehidupan sehari-hari, antara lain untuk mengungkapkan buah pikiran, membangkitkan minat mendengar dan membaca, merupakan alat hubungan kemanusiaan yang baik, mempelajari sifat-sifat manusia, memperlancar kerjasama antar manusia dan lingkungan, serta mempermudah memahami berita atau informasi.

\section{Pengertian Komunikasi Instruksional}

Komunikasi instruksional merupakan kegiatan komunikasi dengan sasaran kelompok yang berisi pengajaran tentang sesuatu pengetahuan atau keterampilan tertentu.

Untuk memudahkan dalam memahami pengertian komunikasi instruksional, Yusup (1990:3) memberikan beberapa contoh bentuk atau turunan komunikasi.
Pertama, komunikasi berlangsung dalam suasana kerumunan orang-orang banyak, misalnya di pasar, di tempat hiburan, dan tempat lainnya yang tidak dikondisikan. Kedua, yaitu komunikasi yang terjadi dalam suasana tertentu, komunikasi di sini tidak lagi bebas, tetapi dikondisikan untuk tujuan-tujuan pendidikan. Ketiga adalah komunikasi instruksional. Di sini komunikasi lebih ditujukan kepada aspek- aspek operasional pendidikan terutama aspek membelajarkan sasaran.

Pembelajaran sebagai salah satu bentuk proses komunikasi di mana pendidik sebagai komunikator, materi pelajaran sebagai pesan media yang digunakan sebagai saluran, peserta didik sebagai komunikan, dan hasil belajar sebagai efek. Dalam komunikasi instruksional ini, tujuan utama yang harus dicapai adalah terjadinya perubahan perilaku peserta didik. Perubahan perilaku yang harus dicapai melalui proses pendidikan mencakup dimensi kognitif, afektif, dan psikomotor.

\section{Gambaran Penggunaan Komunikasi Instruksional oleh Pendidik pada TPA Husnul Khatimah.}

Menurut Muhammad (2005:95) menjelaskan bahwa "komunikasi verbal adalah komunikasi yang menggunakan simbol-simbol atau kata-kata, baik secara oral atau lisan maupun secara tulisan". Secara lisan dapat didefinisikan sebagai suatu proses di mana seorang pendidik berinteraksi secara lisan dengan peserta didik untuk mengubah tingkah laku peserta didik, misalnya pendidik menyuruh peserta didik untuk menghafal ayat-ayatAL-Quran disertakan dengan tajwid dan irama.

Komunikasi nonverbal menurut Muhammad (2005:130) mengartikan komunikasi nonverbal adalah penciptaan dan pertukaran pesan dengan tidak menggunakan kata-kata, seperti komunikasi menggunakan gerak tubuh, sikap tubuh, vokal yang bukan kata-kata, kontak mata, ekspresi muka, kedekatan jarak, dan sentuhan. Dalam komunikasi nonverbal, orang dapat mengekspresikan perasaannya melalui gerakan tubuh, meliputi kontak mata, ekspresi wajah, isyarat,sikap tubuh, dan postur secara efektif dapat menyampaikan pesan yang akan memperkuat komunikasi. Gerakan tubuh biasanya digunakan untuk menggantikan suatu 
kata, misalnya mengangguk untuk mengatakan "ya". Untuk menjelaskan sesuatu, menunjukkan perasaan, misalnya memukul meja untuk menunjukkan kemarahan.

Selanjutnya komunikasi bermedia adalah suatu proses penyampaian pesan / informasi oleh pendidik kepada peserta didik dengan menggunakan alat atau sarana sebagai media yang dapat mendukung penyampaian materi. Menurut Onong (2000:380), proses komunikasi dengan menggunakan media semakin lama semakin efektif dan efisien karena didukung oleh teknologi komunikasi yang canggih, yang ditopang juga oleh teknologi lainnya yang bukan teknologi komunikasi. Sebagai contoh, komunikator menggunakan media jika jumlah sasaran komunikasinya banyak yang memungkinkan suara atau informasi yang disampaikan itu tidak terdengar jelas maka dipakailah pengeras suara.

Komunikasi merupakan sesuatu yang penting dan menentukan dalam mencapai tujuan organisasi / lembaga, termasuk ke dalamnya lembaga pendidikan. Oleh sebab itu, sudah merupakan kebutuhan dasar yang harus dimiliki oleh setiap pendidik dalam menjalankan aktivitasnya untuk mencapai tujuan yang telah digariskan dalam kegiatan pembelajaran, yaitu hasil belajar dari peserta didik itu sendiri.

Adapun kerangka berpikirnya tertuang dalam bagan di bawah ini.

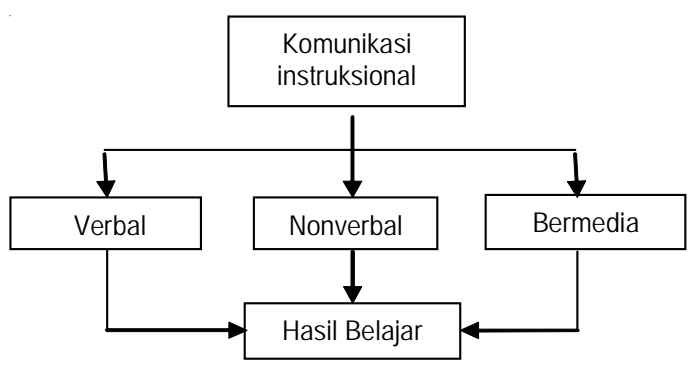

Gambar 1. Kerangka berpikir komunikasi belajar

\section{METODOLOGI PENELITIAN}

Penelitian ini dirancang dalam bentuk deskriptif. Populasi dalam penelitian ini adalah seluruh murid pada TPA Husnul Khatimah, yang berjumlah 152 orang terdiri dari kelas I berjumlah 62 orang, kelas II berjumlah 48 orang, dan kelas III berjumlah 42 orang. Besarnya sampel dalam penelitian ini adalah $25 \%$ dari jumlah populasi.

Penarikan sampel menggunakan stratified random sampling yang berjumlah sebanyak 37 orang. Data diambil dari TPA dengan teknik pengumpulan data berupa wawancara. Adapun instrumen yang digunakan adalah pedoman wawancara. Data yang terkumpul dianalisis dengan menggunakan rumus persentase:

$$
\mathrm{P}=\frac{F}{N} \times 100 \%
$$

\section{Keterangan :}

$\mathrm{P}=$ persentase yang akan dicari

$\mathrm{F}=$ frekuensi atau jumlah jawaban

$\mathrm{N}=$ jumlah responden

Jenis dan sumber data yang digunakan adalah data primer karena langsung diperoleh dari peserta didik pada TPA Husnul Khatimah. Instrumen penelitian disusun dengan cara menjabarkan variabel kepada subvariabel.

Setelah itu, subvariabel ditetapkan, barulah dirumuskan butir pertanyaan untuk mengetahui penggunaan komunikasi instruksional oleh pendidik dalam menyampaikan pesan verbal, nonverbal, dan menggunakan media dengan skala penilaian selalu (SL), jarang (JR), dan tidak pernah (TP).

\section{HASIL PENELITIAN}

\section{Gambaran Penggunaan Komunikasi Instruksional oleh Pendidik dalam Bentuk Menyampaikan Pesan Verbal.}

Penggunaan komunikasi instruksional dalam bentuk menyampaikan pesan verbal diungkap melalui persepsi peserta didik melalui indikator: 1) penyampaian pesan secara lisan yang terdiri dari bahasa atau kata-kata yang digunakan, volume suara, penekanan nada, logat, sikap dan kejelasan, 2) penyampaian pe- san secara tertulis yang dilihat dari bahasa atau pemilihan kata-kata, dan kejelasan.

Dari indikator dijabarkan 19 butir pertanyaan dengan alternatif SL (selalu), SR (sering), JR (jarang), dan TP (tidak pernah). Untuk lebih jelasnya hasil pengolahan data tentang penggunaan komunikasi instruksional oleh pendidik dalam bentuk menyampaikan pesan verbal. Hal ini terbukti dari jawaban yang diberikan oleh 37 orang responden sebagai peserta didik pada 
TPA Husnul Khatimah untuk masing-masing item sehubungan dengan penyampaian pesan verbal.

Dalam penyampaian pesan verbal, pendidik cenderung selalu $(94,6 \%)$ menggunakan kata yang jelas, dan hanya $(5,4 \%)$ peserta didik yang menjawab sering. Dalam komunikasi lisan, pendidik selalu $(75,7 \%)$ menggunakan bahasa yang mudah dimengerti sehingga materi pelajaran yang disampaikan bisa dipahami dengan cepat, dan $(24,3 \%)$ yang menyatakan sering pendidik menggunakan bahasa yang mudah dimengerti. Dalam komunikasi verbal, pendidik selalu $(100 \%)$ menyampaikan materi dengan suara yang jelas dan lantang serta informasi yang disampaikan dan dituliskan di papan tulis itu berkaitan dengan materi yang dibahas.

Pada waktu penyampaian materi pendidik selalu $(45,9 \%)$ bisa menyesuaikan volume suara dengan jumlah peserta didik, dan $(35,1 \%)$ pendidik sering menyesuaikannya, $(18,9 \%)$ pendidik jarang memperhatikan hal tersebut. Logat yang digunakan oleh pendidik menarik dan penekanan pada kata-kata pun sangat tepat sehingga apa yang disampaikan bisa dimengerti langsung, $(40,5 \%)$ peserta didik menyatakan selalu, $(45,9 \%)$ peserta didik menyatakan sering dan (13,5\%) peserta didik menyatakan jarang. Pendidik selalu $(51,4 \%)$ menggunakan intonasi untuk mempertegas pesan, $(37,8 \%)$ sering, dan $(10,8 \%)$ pendidik jarang memperhatikan intonasi untuk mempertegas pesan.

Peserta didik menyatakan bahwa pendidik selalu $(62,2 \%)$ bersikap ramah dalam proses belajar mengajar dan selalu di hubungkan dengan kehidupan sehari-hari. Sementara penyampaian pesan dengan cara tertulis, pendidik cenderung selalu $(97,3 \%)$ menggunakan tulisan yang bisa dimengerti oleh peserta didik, $(2,7 \%)$ sering, dan $(0 \%)$ yang mengatakan jarang dan tidak pernah. Dengan begitu, materi yang dituliskan tersebut selalu (73\%) bisa dipahami oleh peserta didik, dan (27\%) menyatakan sering. Begitu juga halnya dengan istilahistilah yang dituliskan pendidik $(56,8 \%)$ mengatakan selalu bisa dipahami, dan $(37,8 \%)$ sering bisa dipahami, dan $(5,4 \%)$ jarang bisa dipahami. Dalam proses belajar mengajar, pendidik memiliki sikap yang ditunjukkan dengan persentase selalu $(62,2 \%)$, yang menyatakan sering $(37,8 \%)$, dan $(10,8 \%)$ peserta didik menyatakan jarang.

Dari uraian di atas maka dapat diambil kesimpulan bahwa penggunaan komunikasi instruksional oleh pendidik dalam bentuk menyampaikan pesan verbal pada TPA Husnul Khatimah sudah dilakukan dengan baik. Terlihat dari perbandingan rata-rata persentase $(71,4 \%)$ menyatakan selalu, $(23,4 \%)$ menyatakan sering, $(5,1 \%)$ menyatakan jarang, dan $(0 \%)$ respon menyatakan tidak pernah.

\section{Gambaran Penggunaan Komunikasi Instruksional oleh Pendidik dalam Bentuk Penyampaian Pesan Nonverbal}

Penggunaan komunikasi instruksional dalam bentuk menyampaikan pesan nonverbal diungkap melalui persepsi peserta didik melalui indikator: 1) penyampaian pesan yang disertakan dengan ekspresi muka, 2) penyampaian pesan yang disertakan dengan gerak tubuh, dan 3) penyampaian pesan yang disertakan gaya bicara. Indikator tersebut dijabarkan menjadi tujuh butir pertanyaan dengan alternatif $\mathrm{SL}$ (selalu), SR (sering), JR (Jarang), dan TP (tidak Pernah). Untuk lebih jelasnya hasil pengolahan data tentang penggunaan komunikasi instruksional oleh pendidik dalam bentuk penyampaian pesan nonverbal, sebagaimana data yang diperoleh dari 37 orang responden peserta didik pada TPA Husnul Khatimah sudah bagus. Hal ini dapat dilihat dari hasil persentase yang diperoleh untuk masing-masing item yang diajukan.

Dalam komunikasi nonverbal, pendidik memberikan senyuman pada waktu memulai pelajaran yang ditunjukan dengan $(35,1 \%)$ peserta didik menyatakan selalu, $(35.1 \%)$ peserta didik menyatakan sering, dan $(29,7 \%)$ peserta didik menyatakan bahwa peserta didik jarang memberikan senyuman jika memulai pelajaran. Peserta didik memandang bahwa kata-kata yang diucapkan pendidik diikuti oleh mimik wajah, yaitu selalu dan sering ditunjukan dengan persentase yang sama yaitu $(48,6 \%)$ dan menyatakan jarang $(2,7 \%)$. Persentase paling tinggi $(78,4 \%)$ yaitu selalu pendidik menyampaikan materi disertakan dengan ekspresi tubuh, $(21,6 \%)$ pendidik sering menyampaikan materi di sertai dengan ekspresi tubuh, dan $(0 \%)$ tidak pernah menggunakan ekspresi tubuh.

Bila peserta didik melakukan kesalahan, pendidik selalu $(29,7 \%)$ mengelengkan kepala, menandakan melarang, dengan jumlah persen yang sama menyatakan sering, $(40,5 \%)$ menyatakan jarang, $(0 \%)$ menyatakan tak pernah. Apabila peserta didik memperlihatkan kelebihan, seperti prestasi pendidik selalu $(27 \%)$ memberikan pujian dengan mengacungkan jempol, $(45,7 \%)$ sering, dan (27\%) menyatakan jarang. Pada waktu berkomunikasi, pendidik selalu $(70,3 \%)$ berusaha mendekat dengan peserta didik, $(24,3 \%)$ sering, dan $(5,4 \%)$ pendidik jarang mendekat dengan peserta didik. Pendidik selalu $(70,3 \%)$ berusaha mendekati peserta didik, $(24,3 \%)$ sering, dan $(5,4 \%)$ jarang mendekat dengan peserta didik.

Dari uraian di atas dapat disimpulkan bahwa penggunaan komunikasi instruksional oleh pendidik dalam bentuk menyampaikan pesan nonverbal pada 
TPA Husnul Khatimah sudah dilakukan dengan cukup baik. Ini terlihat dari perbandingan persentase $(51,3 \%)$ menyatakan selalu, $(33,6 \%)$ menyatakan sering, dan (15\%) peserta didik menyatakan jarang.

Gambaran Penggunaan Komunikasi Instruksional oleh Pendidik dalam Bentuk Menyampaikan Pesan dengan Menggunakan Media.

Penggunaan komunikasi instruksional oleh pendidik dalam bentuk menyampaikan pesan dengan menggunakan media indikatornya, yaitu 1). Persiapan media, 2). Pengetahuan tentang media, 3). Keterampilan penggunaaan media. Indikator ini dijabarkan menjadi sembilan butir pertanyaan yang akan diungkap melalui persepsi peserta didik sebagai responden yang sudah ditetapkan.

Penggunaan komunikasi instruksional oleh pendidik dengan menggunakan media diuraikan, sebagai berikut persentase tertinggi $(91,9 \%)$ selalu mempersiapkan media yang akan digunakan, $(8,1 \%)$ sering, serta $(0 \%)$ jarang dan tidak pernah pendidik mempersiapkan media yang digunakan. Media yang digunakan pendidik selalu $(94,6 \%)$ mendukung penyampaian materi, $(5,4 \%)$ sering, serta $(0 \%)$ menyatakan jarang dan tidak pernah mendukung penyampaian materi. Pendidik selalu $(51,4 \%)$ menyesuaikan median dengan kemampuan peserta didik, $(35,1 \%)$ menyatakan sering, serta $(0 \%)$ jarang dan tidak pernah meng- gunakan media yang disesuaikan dengan kemampuan peserta didik.

Dalam hal penggunaan media, pendidik memiliki kemampuan yang profesional $(89,2 \%)$, peserta didik menyatakan selalu, dan $(10,8 \%)$ sering. Di samping itu, pendidik juga menyesuaikan jenis media dengan materi yang disampaikan, $(54,1 \%)$ menyatakan selalu, $(32,4 \%)$ sering, $(13,5 \%)$ menyatakan jarang, dan $(0 \%)$ menyatakan tidak pernah. Peserta didik merasa materi yang disampaikan dengan menggunakan media itu jelas, $(86,5 \%)$ menyatakan selalu, $(13,5 \%)$ menyatakan sering. Di samping menggunakan media dapat memperjelas penyampaian pesan juga bisa peserta didik mempermudah peserta didik dalam memahami pesan, $(67,6 \%)$ menyatakan selalu dan $(32,4 \%)$ sering. Selain itu, mereka juga merasa akan lebih mudah memahami materi jika penyampaiannya dengan menggunakan media. $(89,2 \%)$ menyatakan selalu, $(10,8 \%)$ menyatakan sering, $(0 \%)$ peserta didik menyatakan jarang dan tidak pernah.

Maka dapat diambil kesimpulan bahwa penggunaan komunikasi instruksional oleh pendidik dalam bentuk menyampaikan pesan dengan menggunakan media sudah di lakukan dengan baik. Terlihat dari perbandingan rata-rata persentase $(74,5 \%)$ menyatakan selalu, $(21 \%)$ menyatakan sering, $(4,5 \%)$ menyatakan jarang, dan $(0 \%)$ menyatakan tidak pernah.

\section{PEMBAHASAN}

\section{Penggunaan Komunikasi Instruksional oleh Pendidik dalam Bentuk Menyampaikan Pesan Verbal pada TPA Husnul Khatimah.}

Pendidik dituntut untuk lebih menguasai komunikasi verbal mengingat bahwa dalam kesehariannya lebih banyak menggunakan komunikasi ini. Hal ini terlihat dari pengarahan-pengarahan, ceramah-ceramah yang diberikan, instruksi-instruksi, maupun pertemuan tatap muka antara dua orang atau lebih, baik direncanakan maupun tidak direncanakan. Sebagaimana yang dijelaskan Wursanto (dalam gusni, 2007) mengemukakan bahwa "komunikasi secara lisan berisikan perintah, instruksi yang dipergunakan dalam hal-hal yang sifatnya sederhana, rutin, mendesak, rahasia, serta pelaksanannya memerlukan waktu yang singkat".

Dari pendapat di atas dapat disimpulkan, bahwa penyampaian pesan secara lisan merupakan kegiatan rutin, oleh karena itu, komunikator harus mampu melaksanakannya dengan sebaik-baiknya. Hal ini menunjuk- kan bahwa pendidik pada TPA Husnul Khatimah sudah menggunakan kata-kata yang cukup jelas, bisa dipahami dan dimengerti oleh peserta didik. Selain itu, logat, intonasi, dan volume suara dari pendidik sudah cukup baik ada menarik bagi peserta didik.

Artinya komunikasi verbal yang digunakan oleh pendidik dalam proses belajar mengajar pada TPA Husnul Khatimah sudah cukup baik. Dalam proses komunikasi, bahasa merupakan lambang verbal yang paling digunakan, karena hanya bahasa yang mampu mengungkapkan pikiran dari komunikator mengenai hal atau peristiwa baik yang konkret atau abstrak, yang terjadi di masa kini, masa lalu, dan masa yang akan datang. Sebagaimana yang dijelaskan oleh Sudjana (2005:31) "Bahwa untuk mencapai interaksi belajar mengajar sudah barang tentu perlu, adanya komunikasi yang jelas antara pendidik dengan peserta didik, sehingga terpadunya dua kegiatan, yakni kegiatan mengajar dengan kegiatan belajar yang berdaya guna 
dalam mencapai tujuan pengajaran". Tujuan yang terdapat dalam komunikasi adalah memberitahu atau mengubah sikap, pendapat, atau perilaku. Sementara dalam komunikasi instruksional baik yang formal maupun nonformal, tujuan utama yang harus dicapai di dalamnya adalah terjadinya perubahan perilaku pada peserta didik.

Yusup (1990:5) menjelaskan "komunikasi instruksional lebih ditekankan pada pola perencanaan dan pelaksanaan secara operasional yang didukung teori untuk kepentingan keberhasilan, yaitu efek perubahan perilaku pada pihak sasaran dan efek inilah yang merupakan tujuan akhir dari pelaksanaan komunikasi instruksional".

Penggunaan Komunikasi Instruksional oleh Pendidik dalam Bentuk Menyampaikan Pesan Nonverbal pada TPA Husnul Khatimah.

Keberhasilan proses komunikasi tidak terlepas dari faktor etos pada komunikator. Seperti yang di kemukakan oleh Onong (2000:305) bahwa "dalam proses komunikasi seorang komunikator akan sukses apabila ia berhasil menunjukkan source credibility, artinya sumber kepercayaan". Kepercayaan di sini maksudnya, yaitu kepercayaan komunikan kepada komunikator ditentukan oleh keahlian dari komunikator. Kepercayaan dalam menyampaikan pesan sebagai tugas pekerjaannya dan komunikan menentukan dapat atau tidaknya ia dipercaya dalam menjalani tugas tersebut. Jika seorang pendidik dalam aktivitas pembelajaran dapat mengekspresikan materi pelajaran yang disampaikan kepada peserta didik dengan baik sebagai hasil aktivitas pembelajaran tertentu akan memberikan hasil yang baik pula pada peserta didik. Karena prestasi yang diperoleh peserta didik dalam kegiatan belajar dapat dijadikan sebai alat peramal bagi keberhasilan pendidik dalam berkomunikasi.

Seperti yang diungkapkan Muhammad (2005:130) bahwa komunikasi nonverbal adalah "Penciptaan dan pertukaran pesan dengan tidak menggunakan kata-kata, seperti komunikasi yang menggunakan gerak tubuh, sikap tubuh, vokal yang bukan kata-kata, kontak mata, ekspresi muka, kedekatan jarak, dan sentuhan". Semakin baik kemampuan berkomunikasi nonverbal oleh pendidik akan semakin tinggi pula hasil belajar dari peserta didik. Sebaliknya, apabila pendidik mengabaikan masalah komunikasi nonverbal ini atau tidak menerapkan dalam proses pembelajaran, akan dapat menyebabkan rendahnya hasil belajar peserta didik. Sehubungan dengan hal di atas seharusnyalah pendidik untuk dapat menerapkan komunikasi instruksional dalam bentuk penyampaian pesan nonverbal, sehingga tujuan yang telah ditetapkan dapat tercapai.

Berdasarkan hasil penelitian menunjukan persentase paling tinggi yang menunjukan skor pada kriteria cukup baik. Peserta didik menyatakan bahwa pendidik dalam menyampaikan materi disertai dengan ekspresi tubuh. Ini menunjukkan bahwa pendidik berusaha menyampaikan materi sedemikian rupa yang disertai dengan ekspresi tubuh agar peserta didik merasa tertarik dengan materi yang disampaikan dan akan mempermudah pencapaian tujuan belajar. Peserta didik menyatakan pendidik memberi senyuman waktu memulai pelajaran, penegasan kata-kata dengan mimik wajah, memberi pujian dengan mengacungkan jempol, menggeleng-gelengkan kepala jika peserta didik melakukan suatu kesalahan, serta berusaha mendekat pada waktu berkomunikasi.

\section{Penggunaan Komunikasi Instruksional oleh Pendidik dalam Bentuk Penyampaian Pesan dengan Menggunakan Media pada TPA Husnul Khatimah.}

Pentingnya media dalam proses komunikasi disebabkan tingkatan keberhasilannya dalam mencapai tujuan komunikasi. Media komunikasi sangat mempengaruhi efektivitas suatu komunikasi dan penggunaannya sangat erat keadaannya dengan si penerima informasi. Pemilihan media komunikasi memerlukan kecakapan dari komunikator itu sendiri dalam hal ini adalah pendidik pada TPA Husnul Khatimah. Karena media itu sendiri berfungsi sebagai alat membangkitkan motivasi, membangkitkan daya tarik pesan yang disampaikan, mengefektifkan proses penyampaian pesan, mempersingkat waktu, dan mempermudah penyampaian informasi.

Hasil penelitian menunjukkan bahwa dalam berkomunikasi, pendidik selalu mempersiapkan dan merancang media yang akan menunjang proses penyampaian pesan, dalam hal ini adalah proses penyampaian materi kepada peserta didik. Pendidik juga sangat memahami media yang akan digunakan, karena itu, pendidik selalu menyesuaikan jenis media yang digunakan tersebut dengan materi yang akan disampaikan. Peserta didik mengatakan selalu, bahwa penggunanan media itu mendukung penyampaian materi. Pendidik sebagai pemimpin dalam proses pembelajaran harus memiliki keterampilan/kemampuan dalam berkomunikasi dengan menggunakan media secara baik dan lancar. Hal ini akan mendukung dalam pencapaian tujuan pelaksanaan pembelajaran.

Berdasarkan temuan di atas menunjukkan bahwa komunikasi instruksional dalam bentuk penyampaian pesan dengan menggunakan media oleh pendidik sudah terlaksana dengan sangat baik. Perencanaan 
media adalah bagian dari program komunikasi. Perencanaan media merupakan upaya memperoleh langkah- langkah yang paling efektif sebagai dukungan dalam mencapai tujuan yang diharapkan dengan baik.

\section{KESIMPULAN}

\section{Kesimpulan}

Berdasarkan hasil temuan penelitian dan pembahasan maka dapat disimpulkan secara umum penggunaan komunikasi instruksional oleh pendidik pada TPA Husnul Khatimah berjalan dengan baik. Secara khusus dapat disimpulkan sebagai berikut, pertama, penggunaan komunikasi instruksional oleh pendidik dilihat dari komunikasi verbal, nonverbal, dan komunikasi bermedia pada TPA Husnul Khatimah sudah terlaksana dengan cukup baik, yang terlihat dari persentase selalu menunjukan angka tertinggi yang berada pada rentangan klasifikasi cukup baik.

Kedua, penggunaan komunikasi instruksional oleh pendidik dilihat dari komunikasi nonverbal pada TPA Husnul Khatimah, juga terlaksana dengan cukup baik, hal ini dapat dilihat dari persentase selalu menunjukkan angka tertinggi yang berada pada rentangan klasifikasi cukup baik.

Ketiga, penggunaan komunikasi instruksional oleh pendidik dilihat dari komunikasi bermedia pada TPA Husnul Khatimah berjalan dengan baik, hal ini terlihat dari persentase selalu menunjukkan angka tertinggi yang berda pada rentangan klasifikasi baik.

\section{Saran}

Berdasarkan temuan penelitian, pembahasan dan kesimpulan yang telah dikemukakan di atas, ada beberapa saran yang penulis sampaikan sebagai bahan masukan yang diharapkan dapat membantu meningkatkan keterampilan/kemampuan pendidik dalam berkomunikasi, yakni sebagai berikut.

Pertama, penggunaan komunikasi instruksional oleh pendidik dilihat dari komunikasi verbal pada TPA Husnul Khatimah memang terlaksana cukup baik, hanya perlu diperhatikan lagi penekanan nada pada kata-kata serta logat yang dipergunakan oleh pendidik agar materi yang disampaikan lebih bisa dipahami oleh peserta didik.

Kedua, komunikasi nonverbal oleh pendidik dalam proses belajar sudah dilakukan dengan baik, akan tetapi perlu memperhatikan lagi senyuman dalam memulai pelajaran, penegasan kata-kata disertai mimik wajah, serta memberikan pujian kepada peserta didik di saat memperlihatkan prestasi, seperti mem-berikan acungan jempol menandakan bagus, agar peserta didik lebih bersemangat lagi untuk belajar.

Ketiga, dalam komunikasi bermedia sudah baik dan diharapkan dapat terus dipertahankan dan ditingkatkan penggunaanya.

Keempat, untuk peneliti selanjutnya diharapkan dapat meneliti aspek-aspek lain sehubungan dengan komunikasi instruksional, sehingga penelitian ini lebih berkembang.

\section{DAFTAR PUSTAKA}

Fuadiansyah, E. (2007). Persepsi guru terhadap keterampilan berkomunikasi kepala sekolah dasar di kecamatan Sijunjung Kabupaten SawahIunto Sijunjung. Skripsi.

Gusni, Y. (2007). Penggunaan komunikasi instruksional dalam pembelajaran TPA. Sumatera Barat : Universitas Negeri Padang. Skripsi.

Muhammad, A. (2005). Komunikasi organisasi. Jakarta: Bumi Aksara
Onong, U. (2000). IImu, teori, dan filsafat komunikasi. Bandung: PT Citra Aditya Bakti

Sudjana. (2005). Strategi pembelajaran. Bandung: Bina Aksara

Undang-Undang no.20 tahun 2003 tentang sistem pendidikan nasional. (2003)

Yusup, P.M. (1990). Komunikasi pendidikan dan komunikasi instruksional. Bandung:Remaja RosdaKarya 